\title{
Women and Post Harvest Fish Production in the Niger Delta
} Area

\author{
*Ibim Adaba Tonye and Amiye Francis \\ Department of Animal Science and Fisheries, Faculty of Agriculture, University of Port Harcourt, Nigeria
}

\begin{abstract}
The Niger Delta Area of Nigeria is synonymous with large expanse of water bodies: wetlands, coastlines and pondable land areas. Subsequently, the main stay of the people is fishing and fish farming. It is, therefore, of great necessity that persons capable of post harvest production (handling, processing and preservation) be available to utilize the landed catch, in so doing prevent spoilage and financial losses, and adding taste/value to the fish product. Furthermore, food security and sustainable development will be ensured. It has been noted that the sole and primary persons involved in post-harvest production of landed fish in the Niger Delta are women, as they receive the landed fish from the fishers. However, this role of women and the associated challenges are unrecognized. This neglect resulted in the women abandoning their role for "greener pastures", thus creating a vacuum in the food production chain. It is imperative therefore, that these women be empowered, if continuous and improved post harvest production of landed fish is to be enjoyed. Accruing benefits from such developmental programmes summarily, include; improved post harvest products, improved income and living standards of women, prevention of fish spoilage and financial losses, and the ensuring of food security and sustainable development.
\end{abstract}

Key words: Fish, food security, post harvest production, Niger Delta Area, sustainable development and women.

\section{Introduction}

The Niger Delta Area, located in the Southern part of Nigeria. It is Africa's largest delta, covering an area of 70,000 square kilometers; with approximately one third of it made up of wetlands. It is also said to be the third largest world mangrove forest, (Morodion, 2004). It is a prominent area in Nigeria, because of its economic importance as, the source of Nigeria's oil and gas resources and its attendant environmental and social problems among which are; oil spillages, environmental pollution, youth restiveness and their likes, (Morodion, 2004; Ayanwu et al., 2007).

As a result of the presence of large expanse of the aquatic ecosystems in the Niger Delta Area, fish plays a significant role in the diet of the people. It is the primary source of cheap quality protein to its inhabitants, providing up to $75 \%$ of the total animal protein intake and a healthy source of calcium, vitamin A and B, fatty acids and other minerals crucial to good nutrition (Guha, 1974).The dependence of the inhabitants of this area on fish led to fishing, fish culture and post harvest production of fish as the main economic activities of the indigenous people.

It is an accepted socio-cultural practice that over $90 \%$ of the artisanal fish catch are processed (smoked, salted, sun-dried, fried, etc) to prevent massive loss of fish, whereas $10 \%$ or less are sold fresh. Women in the Niger Delta play a crucial role in post-harvest production (processing and preservation) of fish. The women are solely responsible for fish processing, preservation and marketing (Ayinla, 2003; Mochi, 2003 and Ayanwu et al., 2007), either brought by their husbands (fishers) or purchased from fish mongers. According to Williams (1999), fish processing, preservation and marketing is a traditional role of the women in the rural areas. Women are solely responsible for half of the world's food production and between $60 \%$ to $80 \%$ of the food in most developing countries especially post-harvest production.

In most urban areas and developed countries, this key role of fish processing played by women have been recognized and well documented, and developmental programmes of empowerment and enlightenment for improved post-harvest production, have been packaged for women.

In the Niger Delta Area, such developmental programmes have not been put in place. Despite the significant role played by the women, they have been neglected, they are poor illiterates, have no input in decision making/developmental plans that concern them and affect their livelihood. They are regarded as inferior persons in the society and they occupy lower socio-economic status. Thus, they abandon their role at the slightest opportunity to obtain a "brighter future", elsewhere in other jobs. These circumstances need to be reversed. Sustainable rural development and food security through agriculture cannot be achieved without the participation of the women.

There are various strategies that can be adopted for the empowerment of the women, and the girl-child who assists her mother in post-harvest fish production. 
This paper highlights the role, contributions and challenges, of women involved in post-harvest fish production in the Niger Delta, and strategies that could turn-around their socio-economic status for an improved contribution, to development of this region.

\section{INVOLVEMENT OF WOMEN IN POST-HARVEST PRODUCTION.}

Post-harvest production of fish is the handling, processing, and preservation of fish landed by the fishers, in order to prevent spoilage and improve the taste of the fish. Fish, when out of water deteriorates fast except immediate steps are taken to preserve its quality (Bako, 2004). In the Niger Delta Area, it is an accepted socio-cultural practice that, over $90 \%$ of the artisanal catch are processed, and preserved before sales. Often the rest of the catch are marketed fresh with heavy loss of quality (Ayinla, 2003; Bako 2004; Anyanwu et al., 2007). Omorodion (2004) and Williams (1999) also reported that, less than 10\% of the fish caught are consumed fresh while the majority are processed and preserved. In the Niger Delta Area, there are numerous post-harvest techniques available, and include: sun-drying, smoke drying, salt curing, etc. The production technique undertaken determines the type of end product produced e.g. smoke-drying results in smoked fish. In the mangrove area wood is used to smoke-dry the fish and it provides special flavour to the fish being smoked thereby making this a preferable technique for fish smoking (Anyanwu et al., 2007).

Post-harvest fish production is important in ensuring food security. It provides employment and also improves the economic status of the people involved, ensuring sustainable development.

In the Niger Delta, like all coastal communities, fish is the most available and the cheapest source of protein in the diet of the people. According to Ahmed and Rana, (2007), fish is known to play a significant role in the diet, providing up to $75 \%$ of the total animal protein intake.

Traditionally, the women in the Niger Delta play a crucial role in post-harvest production. The role and contribution of women after the fishing expeditions of the men are enormous. They are primarily and in most cases solely responsible for the post-harvest production of fish brought in by their husbands after each fishing trip; and sometimes including catch of other fishers, (Khan, 1998; Gabriel, 2004; Mochi 2003; Ayinla 2003; Bako 2004; Anyanwu et al., 2007). The women are engaged in a wide array of traditional fish processing and preservation activities. The landed fish could be smoke-dried, sun-dried, salted, fermented, dried and grinded, flaked, etc, especially with the unreliability or inconsistency of electrical power in the rural areas. There is a gender division of labour in the Niger Delta communities in the fishery sector (Ekundayo and Kolo, 2003) . The fishing communities rely heavily on family labour where women are the key players or heads, supported mostly by their daughters (Omorodion, 2004). To corroborate this fact, Ogunfowora et al., (2004), reported that approximately $60-80 \%$ of the labour force are women and youth. If the women do not provide the needed labour for the post-harvest activities, the men folks would then be left to handle the additional difficult task. Williams(1999),also reported that, women in female-headed households are also primarily involved in post-harvest production, as an economic activity aimed at improving their house-holds. Thus, it can be seen that the role of women in the fishing communities is significant and timely as noted by Alamu, (1992).Despite this notable role, it is interesting to note that fewer and fewer women are involved in profitable post-harvest production of fish (Williams,1996; Mochi, 2003; Omorodion, 2004; Bako, 2004; Anyanwu et al., 2007).

Regrettably, however, significant contributions of women in post-harvest fish production have been underestimated, under-documented, under-appreciated, under-supported, by prevailing economic policies and other developmental programmes (Williams, 1996; Gabriel, 2004; and Omorodion, 2004). The result is the gross underestimation of women's socio-economic well-being, under-utilization of women's tremendous socioeconomic potentials in rural aquaculture or riverine fisheries in Nigeria and eventually, the reduction in women involved in post-harvest fish production (Ijiff, 1990; Williams, 1999). Even in developed countries, women were also observed to play the vital role of being solely responsible for half of the world's food production . It was noted that, women accounted for $60 \%$ to $80 \%$ of post-harvest production in developing countries. However, in these developed countries, the key role played by women are well recognized, documented and supported (Ijiff, 1990; Williams, 1996), and are enhanced by way of developmental projects, research as well as capacity building, training etc. In the light of what obtains in developed countries, these circumstances in the Niger Delta Area must be reversed. Sustainable rural development and food security cannot be achieved, without women's participation, as their participation is critical, to food security and sustainable development (Mochi, 2003; Anyanwu et al., 2007). Interestingly, women on their part have become increasingly aware of their roles in the society as they form a variety of organizations and actively participate in agricultural development and political affairs (Gabriel, 2004; and Ijiff, 1990). One of such organization in the Niger Delta Area is the Better Life for Rural Women formed by the wife of a former president, Mrs Mariam Babangida(Williams,1999). 


\section{CHALLENGES OF WOMEN IN POST-HARVEST PRODUCTION}

1. Low income generation from marketing of products in the rural areas. Sales of products in the rural areas usually accrues little profit.

2. Limited accessibility to major markets has cut off small-scale producers from sources of inputs, equipment, and buyers, when there is a post-harvest marketable surplus.

3. Limited access to socio-political forum for inputs to policy/decision making and leadership roles, development planning and implementation in Agriculture.

4. Funding of post-harvest production such as loans and developmental grants, from government and other interested bodies are almost non-existent or when available, the interest rates are too high.

5. Individual financial burden - Women bear the burden of survival of their household units for several reasons; either as the primary breadwinner of female - headed households or of their unit within a polygamous homestead. (Omorodion, 2004), for this reason, they can be easily lured into other sectors of the economy that seem to be more profitable.

6. Lack of recognition, under-appreciation and under-support by their communities, States and Federal Government, go a long way to dampen their morals.

7. They work under conditions of great inequality, and frequently receive little direct remuneration for their work.

8. They are faced with poor living conditions as witnessed in many fishing communities in the Niger Delta Area, characterized by overcrowded slums, inadequate services and assets that will enhance living conditions.

9. Poverty leads to early marriages, sexual promiscuity, high rates of sexually transmitted diseases, polygamous marriages, illiteracy, youth restiveness, high crime rate, etc.

10. Lack of access to educational facilities or opportunities, skill acquisition and trainings

11. Lack of access to novel techniques of post-harvest production of fish. Thus, the price of their product is low outside local markets and are unacceptable in quality internationally.

\section{EMPOWERMENT STRATEGIES}

Various economic and educational empowerment strategies are required to develop both the postharvest technology and the women involved in the post-harvest production of fish. These are as follows:

Personal investment: Although this is a long standing practice, and the most common, however, it is limited in scope. This is because personal and families' financial ability to invest in fish processing and preservation is limited, and this will inevitably affect production level. It is an important empowerment tool, but limited in scope to completely turn around the situation.

Formation of fish farmers association: Producers organize themselves into groups known as cooperative societies and associations. Such production cooperatives should include women in the riverine fishing communities or better still production cooperative should be organized for women in the riverine fishing villages. Use of cooperatives is a major means of empowerment presently throughout the country, particularly, now that the federal government has provided soft loans for investment in various aspects of agricultural production.

Access to loans and insurance of farm: Accessibility to loans and credit facilities could be facilitated to finance post-harvest production projects. The high interest rate on agricultural loan in commercial banks, does not allow for establishment of feasible and viable projects. Although the federal government has made available, loans for agricultural activities, most often collaterals are required for disbursement of such loans. In exceptional cases, where collaterals are not demanded, persons are expected to provide a certain percentage of the capital. Besides, the loans are most preferably given to those who already have on-going businesses that wish to expand. Efforts, therefore, must be made by the government to put in place policies that ensure general accessibility to loans, low interest rates and extended payback period.

Role of corporate organizations: One of the vital reasons for so much unrest in the Niger Delta region is poverty, and lack of employment of, women and the young school leavers. The issue of poverty need to be addressed adequately.

Government interventions: Government should establish demonstration farms or industries at local levels to serve as pilot schemes for the fish farmers within their locality. Fish product development projects should also be located in the Niger Delta Area.

Manpower development and training: The Department of Animal Science and Fisheries in the University of Port Harcourt, African Regional Aquaculture Centre (ARAC) Aluu, and the Brackish Water Research Station, Buguma, Rivers State are all located in the Niger Delta region. These institutions have excellent human resource capacity and facilities to take care of every training need in all aspects of post-harvest fish technology. They should be used for the training of women in various aspects of improved post-harvest production technologies that are home-based and with indigenous knowledge that could become cottage 
industries. Also non-governmental bodies can undertake empowerment of the people through capacity building, training and participation in the political process.

Additional services and incentives should be offered in these riverine fishing villages. The women and girls in the Niger Delta should benefit from the rehabilitation projects, planned to stem violence in the Niger Delta. The women and girls should not be neglected while concentrating on the male youths involved in the violent activities in the Niger Delta.

Institutional strengthening can be undertaken to ensure the sustainability of successful development programmes, and the enhancement of the generation and dissemination of technology to increase incomes, family food, improved post-harvest fish product and food security in the long run.

\section{Recommendations}

Access roads to markets and other towns in the Niger Delta Area should be constructed to enhance

trade.

Amenities should be provided in the rural areas to improve living standards (examples of amenities are hospitals/health centers, schools and most especially well built markets for the sales of products.

Education and information by means of bulletins, seminars, meeting and extension work as well as awareness campaigns and scholarship schemes for young women can be packaged, to encourage them to study post-harvest production (fisheries) in order to service women organizations and production systems.

A long range policy is also necessary in harnessing and developing the capabilities of existing fisher folk. It is therefore imperative that close attention is paid to processors through extension services so that they can contribute substantially to the national effort of fishfood production. Unless the attention of the women are captured and their attitudes attuned to upgraded and higher-income-yielding techniques, progress cannot be made. In order to achieve this, there has to be a long range plan. Collaboration and knowledge sharing can help build local research and policy capacities for long-term rural development.

Rural development programming should involve women during both planning and implementation stages.

\section{Conclusion}

Post-harvest production has enormous potentials for food security, income generation and sustainable fisheries/rural development. Improved post-harvest fish production can provide better jobs, improved family livelihood, higher incomes, better lifestyles, etc. Post-harvest production should be regarded as a strong tool for poverty eradication/alleviation. Traditional subsistence post-harvest fish production activities could become commercial enterprises that will bridge the gap between the supply and demand of post-harvest fish product.

Women are primarily or solely responsible for post-harvest production of fish in the Niger Delta Area. Increased women participation should be seen in wider scope for improving the socio-economic conditions of the poor rural fishing households in the Niger Delta Area. Certainly, women are capable of playing greater roles in the post-harvest production of fish, for food security and sustainable development. It is in this context that it has become imperative to develop strategies, and recommendation to deal with these challenges. There is the need therefore to eliminate the problems militating against effective role-performance by the women in the Niger Delta Area. Also women socio-economic situation on this region can be tremendously improved.

\section{References}

[1]. Alamu Aiamu, S.O.,1992. The role of women fish monger on commercial handling and

i. $\quad$ Marketing in JebbaLake Basin. NIFFR Annual Report pp.142-150.

[2]. Ayanwu, P. E., Gabriel, U. U., Akinrotimi, O. A., Bekibele, D. O. and Onunkwo, D. N. 2007. Brackish Water Aquaculture: A Veritable Tool for the Empowerment of Niger Delta communities, (Review). Academic Journals Scientific Research and Essay Vol. 2 (8) 295 - 301 ISSN $1992-2248$ C).

[3]. Ayinla, O. A.,2003. Integrated Aquaculture: A Veritable Tool for Poverty Alleviation/Hunger Eradication in the Niger Delta Region of Nigeria, In: Proceedings of the Conference of Fisheries Society of Nigeria (FISON) 2003, A.A. Eyo, J. O. Ayanda (eds).Pp. $41-49$.

[4]. Catagay, C.,2001. Trade, Gender and Poverty United Nation Development Programme, New York Central Bank of Nigeria. Annual Agric. Survey. 2 (3): 6-7.

[5]. Bako, W. S.,2004. The Role of Women in Fish Processing, Handling and Marketing in Kainji Lake Basin.Proceedings of the $19^{\text {th }}$ Annual Conference of the Fisheries Soc. of Nigeria (FISON) Ilorin $29^{\text {th }}-3^{\text {rd }}$ Dec. 2004.

[6]. Gabriel, A. O. I.,2004. Women in the Niger Delta: Environmental Issues and Challenges in the Third Millennium.

[7]. Ijff, A. M.,1990."Socio-Economic Conditions in Nigerian Fishing Communities". Programme for Integrated Development of Artisanal Fisheries in West Africa, Cotonou, IDAF/ GCP/ RAF/ 192/ DEN. Pp. 119.

[8]. Khan S. Z., 1983.Improvement of the Socio-Economic Condition of Women in Small-scale Fishing Communities. In: Kainji, A Nigerian Man-made Lake. Mabogunje (eds) Pp. 153.

[9]. Mba, N. E. (1982). Nigerian Women Mobilized. Intec Printers Ltd. Ibadan, pp. 344

[10]. Mochi J. (2003). Gender and Aquaculture Development in the African Region. F.A.O. Aquaculture Newsletter 29:35-36.

[11]. Omorodion, F. I. (2004). The Impact of Petroleum Refinery on the Economic Livelihoods of Women in the Niger Delta Region of Nigeria. JENDA: A Journal of Culture and African Women Studies. ISSN: 1530 - 5686, ISSUE 6, pp 1-9. 
[12]. Ogunfowora, O. O., Olusegun T., Omojowo F. S., Alamu S. O., Olowosegun O. M. (2004). A Strategy for Poverty Alleviation in Nigeria through Fisheries Development; Fisheries Society of Nigeria, FISON In: P. A. Araoye (ed) Proceeding of the $19^{\text {th }}$ Annual Conference of the Fisheries Society of Nigeria, Ilorin, Nigeria. pp. $205-213$.

[13]. Williams, S. B. (1996) Economic Role of Women in Fishing Communities: A Case Study of Koko, Nigeria. Pp 1-4. Programme for the Intergrated Development of Artisanal Fisheries FAO Technical Report No: 94 Food and Agric. Org. of the United State.

[14]. Williams, S. B. (1999). The Socio-Economic Potentials of Women in Riverine Small-scale Fisheries in Nigeria. Proceedings of the $7^{\text {th }}$ International Interdisciplinary Congress of Women - Women's Worlds ‘99. Tronsa, Norway 20-26 June 1999. 